\title{
Cryptic Risks to Forest Biosecurity Associated with the Global Movement of Commercial Seed
}

\author{
Michelle Cleary ${ }^{1, *(\mathbb{D})}$, Funda Oskay ${ }^{2}{ }^{(1)}$, Hatice Tugba Doğmuş ${ }^{3}$, Asko Lehtijärvi ${ }^{4}$, \\ Stephen Woodward ${ }^{5}$ and Anna Maria Vettraino ${ }^{6}$ (D) \\ 1 Southern Swedish Forest Research Centre, Swedish University of Agricultural Sciences, Sundsvägen, \\ 23053 Alnarp, Sweden \\ 2 Faculty of Forestry, Çankırı Karatekin University, 18200 Çankırı, Turkey; fundaoskay@karatekin.edu.tr \\ 3 Faculty of Forestry, Isparta University of Applied Sciences, 32260 Isparta, Turkey; \\ tugbadogmus@isparta.edu.tr \\ 4 Bursa Technical University, 16310 Bursa, Turkey; asko.lehtijarvi@btu.edu.tr \\ 5 School of Biological Sciences, University of Aberdeen, Cruickshank Building, Aberdeen AB24 3UU, \\ Scotland, UK; s.woodward@abdn.ac.uk \\ 6 Department for Innovation in Biological, Agro-food and Forest Systems, University of Tuscia, \\ via S. Camillo de Lellis, snc, 01100 Viterbo, Italy; vettrain@unitus.it \\ * Correspondence: Michelle.Cleary@slu.se; Tel.: +46-4041-5181
}

Received: 31 March 2019; Accepted: 21 May 2019; Published: 27 May 2019

\begin{abstract}
The import and export of tree seed carries with it risks of inadvertent introduction of pests and pathogens to hitherto unaffected regions. Although trade in seed of specified trees is regulated, phytosanitary requirements for most tree species are minimal, even those related to the most important forest tree species in a given region. A better understanding of the microbiome associated with seed intended for commercial production or ornamental use, and their potential risk with the transport from the source origin of distributors, will help regulatory agencies implement measures to safeguard seed health and avoid trade-related spread of potentially harmful pathogens. In this study we used high-throughput sequencing to show that highly diverse fungal communities were associated with seed of 14 different Pinus species obtained from seed banks (seed orchards) and retail sources (online distributors) in North America and Europe. Fungal diversity differed among the 23 seedlots tested. Community composition did not relate to the species of Pinus nor the country of origin. Assigned potential functions based on sequence identity using FUNGuild provided an overall understanding of the likely life strategies of fungal operational taxonomic units (OTUs). Of those sequences classified to a trophic level, 453 were plant pathogens, with the Dothideomycetes having the highest prevalence. The most common plant pathogens included Sydowia polyspora, Lasiodiplodia theobromae, Diplodia intermedia and Diplodia sapinea that were detected from the majority of Pinus species. The evidence presented here illustrates an urgent need for plant protection authorities, practitioners and the general public to recognize the potential risk of introducing harmful pathogens through innocent transport of seed.
\end{abstract}

Keywords: alien invasive forest pathogens; emerging forest diseases; global trade; Pinus; Diplodia sapinea; Sydowia polyspora; Lasiodiplodia theobromae; mycobiome

\section{Introduction}

Despite advances in vegetative propagation technologies, production of gymnosperm planting stock in tree nurseries is largely through seed and is likely to remain so for the foreseeable future for most species used in forestry. Seed used for restocking large-scale commercial forests are usually locally sourced, ideally from seed orchards or certified stands growing in the region of production. 
Conversely, for operations requiring smaller numbers of trees or having specific requirements of the host species-variety, as in the ornamentals market, local seed sources generally are not available and the propagation materials, whether it be seed or young plants, must be sourced elsewhere.

Importing tree seed carries an associated risk of inadvertent introduction of harmful pathogens living on or in the seed themselves. Such introductions could lead to establishment and spread of these organisms, affecting nurseries, the young plants therein, and ecosystems into which the seedlings subsequently are planted. This problem is further complicated by the lack of phytosanitary regulations regarding the trade of tree seed in most countries [1]. The Eucalyptus stem canker pathogen Teratosphaeria zuluensis is commonly detected in seeds and seed capsules, and has been moved around the world with Eucalyptus seed used in plantation establishment [2]. Nuts harvested from planted American chestnut (Castanea dentata) were found to be infected by the chestnut blight fungus Cryphonectria parasitica, posing a risk to blight-free areas if fruit were imported [3]. Seed was also noted as the source material by which several tree pathogens arrived to, or moved within, Europe during the 19th and 20th centuries including Diplodia sapinea (syn. Sphaeropsis sapinea), Fusarium circinatum, Nematospora coryli and Pestalotiopsis maculans (syn. Pestalotiopsis guepinii) [4].

Seed of gymnosperms are known to carry, both externally and internally, a number of pathogenic fungi and fungus-like organisms, that may or may not be transmitted to plants growing from the seeds. Some of these fungi cause primarily diseases of the seed (e.g., Caloscypha fulgens causes a seed rot in a number of conifers [5] but has minor effects on other developmental stages of trees). In contrast, seed-borne pathogens of conifers can in some cases result in severe economic and ecological consequences if introduced and become established outside of their natural distribution range. For example, Lasiodiplodia theobromae destroys seeds of various Pinus species in USA, South Africa and Brazil [6-8]. Diplodia sapinea causes tip blight of pines in trees of all ages [9] and has been commonly associated with cones and seeds of various pine species [10,11].

The global and regional transport of seed is also an important pathway for introduction and dissemination of Fusarium circinatum, the causal agent of pine pitch canker. The pathogen is a chronic problem in seedling production because it can cause severe pre- and post-emergence damping off, and lead to dieback and mortality of older pine trees in plantations and forests $[12,13]$. Seed coats and seedling coleoptiles may be colonized by F. circinatum [12]. Dwinell [14] found more post-emergence damping-off in $P$. radiata seedlings grown from $F$. circinatum-contaminated seeds than from uncontaminated seeds. Moreover, it is known that internal contamination of seed results in high rates of infection in germinating seedlings compared with superficial contamination [15]. Fusarium circinatum may also be transported in seed of Douglas-fir (Pseudotsuga menziesii), the only gymnosperm other than members of the genus Pinus known to be susceptible to this pathogen $[16,17]$. Fusarium circinatum is regulated in the European Union (EU) which prohibits the introduction of live plants or plant parts of Pinus species and P. menziesii other than fruit and seed from non-European countries in all member states (Commission Decision 2007/433/EC) [18].

The transport and use of latently infected and/or contaminated seed has been implicated to be a factor in the global movement of several foliar and shoot pathogens. For example, genotypic diversity of $D$. sapinea was consistent with historical records of seed and germplasm importation to and within the southern hemisphere [19]. Seeds of P. menziesii have been suggested as a potential source of infection of the needle cast pathogen Rhabdocline pseudotsugae in addition to the ascospore-based dissemination [20,21]. Bentele et al. [22] also suggested that the needle cast pathogen Lophodermium seditiosum on Scots pine (Pinus sylvestris) could be seed-borne. In general however, there is little information on what diversity of fungi (including contaminants) are found in routinely traded seed materials. Knowledge of these so-called "plant-associated hitchhikers" may be important to assess the potential risk for their establishment and spread in new locations.

The advent of high-throughput sequencing (HTS) opened a new era in fungal ecology [23] that allows for holistic insights into the immense taxonomic (relying on DNA metabarcoding) and functional (metatranscriptomics) diversity of fungi in different niches, with ever-increasing resolution [24-26]. 
Despite the growing body of evidence for its usefulness in the early detection and surveillance of potentially invasive forest pathogens [27-29], and its high sensitivity and capacity to deal with large numbers of samples in less time compared to traditional methods [30], HTS is generally underutilized as a tool in plant biosecurity [31-35].

From a phytosanitary perspective, tree seeds are generally considered safer for trade than live plants [36] primarily because different plant organs on live plants, and in the case of potted plants, also soil, offer a plethora of niches/microhabitats that can carry disease agents from all functional groups of plant pathogens [37]. However, fungal contamination can occur at many stages of seed handling and storage, and this fact receives little recognition or consideration in the seed trade business. Globally, the interest in purchasing seed through online distributors has escalated in recent years; more than 22 million "seed catalogues" can be recovered through a simple online Google search [38], which implies even less control in the global movement of seed. Safeguarding seed health is critically important for avoiding trade-related spread of plant pathogens. Thus, a better understanding of the mycobiota associated with seeds, prior to transport, can add relevant and scientifically-evidenced information for pathway risk analyses for seeds of a particular tree species that may be used for commercial purposes. The aim of this study was to determine the fungal communities present in seeds of a range of Pinus species obtained from both commercial outlets and national seed banks in order to demonstrate the capacity of this pathway to vector potentially harmful plant pathogens and biosecurity risks associated with the trade in seeds.

\section{Materials and Methods}

\subsection{Plant Material}

Seed of a range of Pinus species from different commercial outlets, including seed stands, seed orchards and online internet retailers from four countries: Turkey, Sweden, United States of America (USA) and Portugal was tested (Table 1). With the exception of Sweden, all other country sources included seed of both native and non-native Pinus species. Four species (P. sylvestris, P. pinaster, P. radiata, and P. pinea) were represented in more than one country.

\subsection{DNA Extraction and Sequencing}

From each seed lot, 100 seeds, randomly chosen, were lyophilized for $48 \mathrm{~h}$ in $50 \mathrm{~mL}$ Falcon tubes. Samples were homogenized to powder using a MM200 Retsch ball mill (Retsch GmbH, KG, Haan, Germany) in $25 \mathrm{~mL}$ metal grinding vessels with a $6 \mathrm{~mm}$ diameter stainless steel ball. No surface sterilization was performed on seeds before homogenization since superficial contamination may also represent part of the introduction pathway for some harmful microorganisms. Metal vessels and ball were sterilized by immersing in 5\% sodium hypochlorite for $5 \mathrm{~min}$, followed by $70 \%$ ethanol for $5 \mathrm{~min}$ and then left to dry to avoid any cross-contamination between samples. After homogenization, DNA was extracted from $30 \mathrm{mg}$ of homogenized tissue using the E.Z.N.A. SP Plant DNA Kit (Omega Bio-tek, Doraville, Georgia) following the manufacturer's protocol for dry samples. DNA was quantified using NanoDrop ( ${ }^{\circledR}$ ND-2000 UV/vis Spectrophotometer, Thermo Fisher Scientific Inc., Wilmington, Delaware, USA).

The ITS2 region of the rDNA was amplified by polymerase chain reaction (PCR) using the fungal primers fITS7 and ITS4 $[39,40]$ that were tagged with different 5 ' identifier sequences. For each sample, three replicate PCRs were conducted. Reactions were carried out in $50 \mu \mathrm{L}$ volumes each containing: $5 \mathrm{ng} / \mu \mathrm{L}$ template DNA or $5 \mathrm{ng} / \mu \mathrm{L}$ of sterilized water for the blank, $200 \mu \mathrm{M} \mathrm{dNTPs} ; 750 \mu \mathrm{M} \mathrm{MgCl}_{2}$; $0.025 \mu \mathrm{M}$ Phusion High-fidelity DNA Polymerase (Thermo Scientific), and $200 \mathrm{nM}$ of each primer in $1 \times$ buffer. All reactions were performed in an Eppendorf ${ }^{\circledR}$ Master Cycler ${ }^{\circledR}$. The PCR program consisted of denaturation at $98^{\circ} \mathrm{C}$ for $3 \mathrm{~min}$, followed by 31 cycles of $98{ }^{\circ} \mathrm{C}$ for $30 \mathrm{~s}$, annealing at $57^{\circ} \mathrm{C}$ for $30 \mathrm{~s}$ and extension at $72{ }^{\circ} \mathrm{C}$ for $30 \mathrm{~s}$, before a final extension step at $72{ }^{\circ} \mathrm{C}$ for $7 \mathrm{~min}$. PCR products were purified using Agencourt AMPure XP (Agencourt Bioscience Corp, Massachusetts 
USA) and quantified using a Qubit 3.0 Fluorometer with the Qubit dsDNA HS Assay Kit (Invitrogen, Carlsbad, CA, USA). After quantification, PCR products were pooled in an equimolar mix and sent for sequencing using the Illumina MiSeq platform (Macrogen Inc, Seoul, Korea).

Table 1. Pinus species, source origin, and type of commercial outlet that seedlots were sourced from the four different countries.

\begin{tabular}{|c|c|c|c|c|c|}
\hline $\begin{array}{l}\text { Sample } \\
\text { Code }\end{array}$ & Pinus Species & Geographic Origin & Native State & $\begin{array}{c}\text { Type of Commercial } \\
\text { Outlet }\end{array}$ & $\begin{array}{l}\text { Seedlot Source or } \\
\text { Location }\end{array}$ \\
\hline \multicolumn{6}{|l|}{ Turkey } \\
\hline Ps1 & P. pinaster & Europe & Non-native & Seed stand & Kerpe \\
\hline Ps2 & P. nigra subsp. pallsiana & Europe & Native & Seed orchard & Bartın \\
\hline Ps3 & P. brutia & Europe & Native & Seed orchard & Döşemealtı, Antalya \\
\hline Ps5 & P. sylvestris & Europe & Native & Seed orchard & Sarıkamış \\
\hline Ps6 & P. radiata & California USA, Mexico & Non-native & Seed stand & Kerpe \\
\hline Ps7 & P. halepensis & Europe & Native & Seed stand & Fethiye \\
\hline Ps26 & P. pinea & Europe & Native & Seed stand & Dössemealtı, Antalya \\
\hline \multicolumn{6}{|l|}{ Sweden } \\
\hline Ps10 & P. sylvestris & Europe & Native & Seed orchard & Moliden \\
\hline Ps11 & P. sylvestris & Europe & Native & Seed orchard & Lycksta \\
\hline Ps12 & P. sylvestris & Europe & Native & Seed orchard & Gotthardsberg \\
\hline \multicolumn{6}{|l|}{ USA } \\
\hline Ps13 & P. sylvestris & Europe & Non-native & Internet order & $\mathrm{n} / \mathrm{a}^{*}$ \\
\hline Ps14 & P. thunbergii & Asia & Non-native & Internet order & $\mathrm{n} / \mathrm{a}$ \\
\hline Ps15 & P. patula & Mexico & Non-native & Internet order & $\mathrm{n} / \mathrm{a}$ \\
\hline Ps16 & P. taeda & Eastern USA & Native & Internet order & $\mathrm{n} / \mathrm{a}$ \\
\hline Ps17 & P. densiflora & Asia & Non-native & Internet order & $\mathrm{n} / \mathrm{a}$ \\
\hline Ps18 & P. radiata & California USA, Mexico & Native & Internet order & $\mathrm{n} / \mathrm{a}$ \\
\hline Ps19 & P. elliottii & Southeastern USA & Native & Internet order & $\mathrm{n} / \mathrm{a}$ \\
\hline \multicolumn{6}{|l|}{ Portugal } \\
\hline Ps20 & P. strobus & Eastern USA and Canada & Non-native & Seed stand & $\mathrm{n} / \mathrm{a}$ \\
\hline Ps21 & P. mugo & Central Europe & Non-native & Seed stand & $\mathrm{n} / \mathrm{a}$ \\
\hline Ps22 & P. pinaster & Europe & Native & Seed stand & $\mathrm{n} / \mathrm{a}$ \\
\hline Ps23 & P. sylvestris & Europe & Native & Seed stand & $\mathrm{n} / \mathrm{a}$ \\
\hline Ps24 & P. radiata & California USA, Mexico & Non-native & Seed stand & $\mathrm{n} / \mathrm{a}$ \\
\hline Ps25 & P. pinea & Europe & Native & Seed stand & $\mathrm{n} / \mathrm{a}$ \\
\hline
\end{tabular}

\subsection{Bioinformatics and Analysis of Sequence Data}

Analysis and annotation of output data were carried out using the QIIME data analysis package [41]. Sequences were processed using QIIME version 1.9 [41]. Poor quality reads $(<\mathrm{Q} 20$, minimum length $=$ $150 \mathrm{bp}$, homopolymer $=6 \mathrm{bp}$ ) were removed. All sequence files were combined into a single fasta file. Sequences were dereplicated and singletons were removed using the sequence analysis tool USEARCH (http://www.drive5.com/usearch/). Following sequence clustering at $97 \%$ similarity using the UPARSE algorithm implemented in USEARCH which included chimera detection and filtering, each sequence was searched using the Basic Local Alignment Search Tool (BLAST) at the NCBI website. No fungal sequences were removed. Operational taxonomic units (OTUs) with identity and coverage $\geq 97 \%$ were assigned to a species level and below that threshold, to a genus or family level [35].

The FUNGuild database v1.0 database (https://github.com/UMNFuN/FUNGuild) was used to assess the ecological and functional diversity in samples of OTUs identified to the species level [42]. Trophic levels included: pathogens (in FUNGuild referred to as pathotrophic fungi), saprotrophs, and mutualists (in FUNGuild referred to as symbiotrophic fungi). Fungal taxa categorized into combined pathogen-saprotroph or pathogen-mutualist trophic levels included those that may exhibit different life styles depending on life cycle stage, environmental conditions, or both.

All data analyses were conducted in $R$ version 3.5.1 (R Core team, 2018) using the vegan package version 2.4 [43]. The number of sequences per sample was normalized to the smallest sample size in order to remove sample heterogeneity. The relative abundance of a specific fungal OTU was defined as the percentage number of reads where the OTU was detected relative to the total number of reads in a sample. A rarefaction curve plot was generated showing the number of OTUs versus the number of 
sequences (reads). Richness was estimated with the Chao1 richness estimator (a nonparametric method for estimating the number of species in the community, considering also rare OTUs) using the formula: Schao1 $=$ Sobs $+\{n 1(n 1-1) / 2(n 2+1)\}$, where Sobs is the number of observed species/OTUs, $n 1$ is the number of OTUs that contained only one sequence, and $n 2$ is the number of OTUs that contained two sequences. The Shannon index, which measures the diversity of communities considering both species richness and evenness, was calculated using the formula $\mathrm{H}^{\prime}=-\Sigma \mathrm{p} i \mathrm{ln}(\mathrm{p} i)$, where $\mathrm{p}$ is the relative abundance of the phylotypes.

The 'plant pathogen' community composition among samples was visualized using non-metric dimensional scaling (NMDS) on a Bray-Curtis distance matrix. A heatmap of relative abundances of the most dominant plant pathogens was generated and samples were sorted based on Bray-Curtis distance. The sequences of the four most abundant SpOTUs (i.e., plant pathogens identified to species level) were aligned with known sequences in GenBank, using ClustalW [44]. Neighbour joining analysis, based on K2P distances and tested by 1000 bootstrap replicates, was conducted for each alignment to confirm the identification of query sequence to the genus or species level, using PHYLIP 3.6 [45] and trees were drawn using TreeView [46].

\section{Results}

\subsection{Structure of the Fungal Communities of Pinus Species}

After quality filtering and sequence processing, we obtained large data sets, ranging between 52,054 and 230,458 (average $=96,330 \pm 7857$ ) fungal sequences per sample. Rarefying at the lowest recovery threshold, a total of 1997 unique fungal OTUs were recorded from the 23 seedlots. The rarefaction curves based on OTU numbers showed that all the samples reached the saturation plateau, and that the sequencing effort revealed the full diversity of the fungal community (Figure 1).
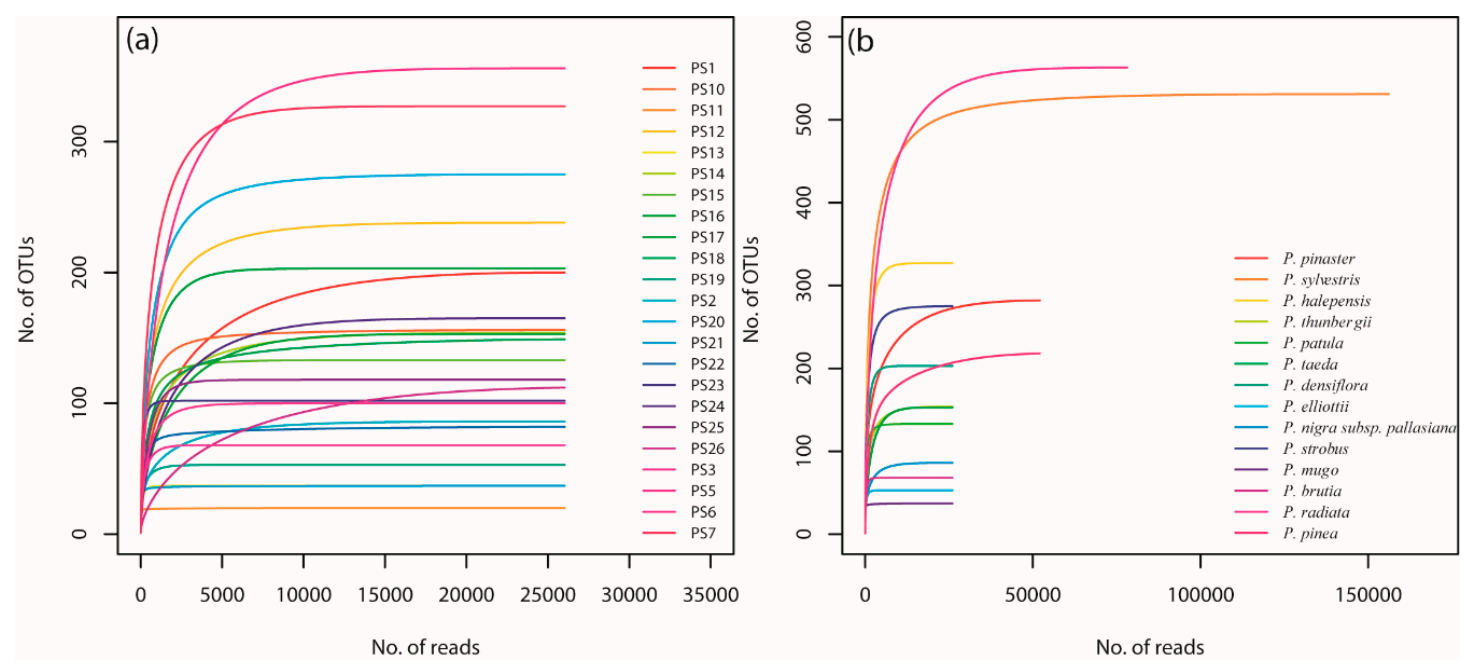

Figure 1. Diversity of fungi in a range of Pinus spp. seedlots. (a) Rarefaction curve of operational taxonomic units (OTUs) in each seed sample plotted against the number of pyrosequencing reads excluding singletons. The numbers represent sample ID (Table 1); (b) Rarefaction curve of OTUs for each Pinus species plotted against the number of pyrosequencing reads excluding singletons. OTUs were clustered conservatively at $97 \%$ similarity.

A diverse population of fungi was associated with seeds of Pinus species sourced from the four different countries (Supplementary File 1). Ascomycota dominated the fungal community, representing $53 \%$ of the OTUs. The second most abundant phylum was Basidiomycota, representing $21 \%$ of the OTUs. The abundance of the OTUs assigned to the Chytridiomycota and Zygomycota phyla were $0.1 \%$ and $1.4 \%$, respectively. Approximately $25 \%$ of reads could not be assigned to any phylum. 
Chao1 richness estimates showed a large disparity among samples. An average of 144.5 taxa per sample were detected. Chao1 values ranged from 20 (P. sylvestris, Sweden, Ps11) to 356 (P. radiata, Turkey, Ps6). Sample Ps26 (P. pinea, Turkey) had the lowest Shannon index value (0.8114) while Ps7 (P. halepensis, Turkey) had the highest (4.222) (Table 2). However, neither total fungal community nor plant pathogen community were significantly affected by geographic origin of seeds. In addition, based on Chao and Shannon diversity indices, there were no significant differences among native and non-native Pinus species.

Table 2. Shannon index $(\mathrm{H})$ and Chao1 richness of the total fungal community associated with seed samples of Pinus species from different countries.

\begin{tabular}{|c|c|c|c|c|c|}
\hline \multirow{2}{*}{ Sample Code } & \multirow{2}{*}{ Pinus Species } & \multicolumn{2}{|c|}{ Total Fungal Community } & \multicolumn{2}{|c|}{ "Plant pathogens" } \\
\hline & & Chao1 & Shannon_H & Chao1 & Shannon_H \\
\hline \multicolumn{6}{|l|}{ Turkey } \\
\hline Ps1 & P. pinaster & 200 & 2.833 & 26 & 1.424 \\
\hline Ps2 & P. nigra subsp. pallsiana & 86 & 2.538 & 22 & 1.621 \\
\hline Ps3 & P. brutia & 68 & 1.899 & 23 & 0.8489 \\
\hline Ps5 & P. sylvestris & 100 & 1.871 & 24 & 1472 \\
\hline Ps6 & $P$. radiata & 356 & 2.895 & 36 & 1.603 \\
\hline Ps7 & P. halepensis & 327 & 4.222 & 65 & 2.165 \\
\hline Ps26 & P. pinea & 112 & 0.8114 & 43 & 0.661 \\
\hline \multicolumn{6}{|l|}{ Sweden } \\
\hline Ps10 & P. sylvestris & 156 & 2.562 & 28 & 0.6453 \\
\hline Ps11 & P. sylvestris & 20 & 1.91 & 10 & 1.449 \\
\hline Ps12 & P. sylvestris & 238 & 3.254 & 36 & 1.47 \\
\hline \multicolumn{6}{|l|}{ USA } \\
\hline Ps13 & P. sylvestris & 37 & 2.377 & 6 & 0.931 \\
\hline Ps14 & P. thunbergii & 154 & 2.461 & 59 & 1.692 \\
\hline Ps15 & P. patula & 133 & 3.215 & 18 & 2.182 \\
\hline Ps16 & P. taeda & 153 & 1.78 & 54 & 1.181 \\
\hline Ps17 & P. densiflora & 203 & 3.119 & 52 & 1.902 \\
\hline Ps18 & P. radiata & 149 & 2.439 & 51 & 1.405 \\
\hline Ps19 & P. elliottii & 53 & 2.608 & 28 & 2.254 \\
\hline \multicolumn{6}{|l|}{ Portugal } \\
\hline Ps20 & P. strobus & 275 & 3.898 & 69 & 2.541 \\
\hline Ps21 & P. mugo & 37 & 2.583 & 8 & 1.769 \\
\hline Ps22 & P. pinaster & 82 & 2.323 & 28 & 0.9963 \\
\hline Ps23 & P. sylvestris & 102 & 3.79 & 18 & 2.136 \\
\hline Ps24 & P. radiata & 165 & 1.495 & 30 & 0.2639 \\
\hline Ps25 & P. pinea & 118 & 2.147 & 86 & 2.115 \\
\hline
\end{tabular}

The ecological functions of approximately $47 \%$ OTUs $(n=945)$ were not defined. The remaining OTUs comprised saprotrophs, pathogens-saprotrophs-symbionts and pathogens, at $21 \%, 12 \%$ and $10 \%$, respectively. A total of 212 OTUs (10\%) had life strategies in five other guilds (Figure 2).

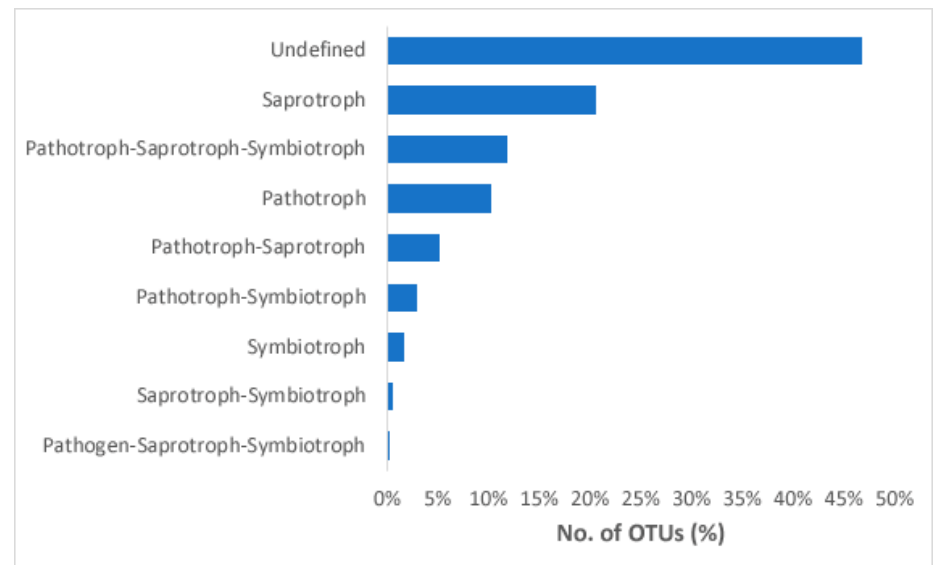

Figure 2. Relative abundance of fungi in seed assigned to different trophic levels in FUNGuild. Trophic modes include: pathogen [pathotroph], saprotroph, and mutualist [symbiotroph], and combinations thereof. 


\subsection{Structure of the Plant Pathogen Community in Pinus Species Seed}

A considerable number of sequences grouped in the fungal guild "Plant Pathogen". Of the total number of OTUs, 453 (23\%) were classified as plant pathogens of which $60 \%$ were identified to the species level (SpOTUs $=276$ OTUs). Ascomycota was the most prevalent phylum (representing $95 \%$ of all SpOTUs). Taxonomic classifications of SpOTUs from the Ascomycota are shown in Figure 3.

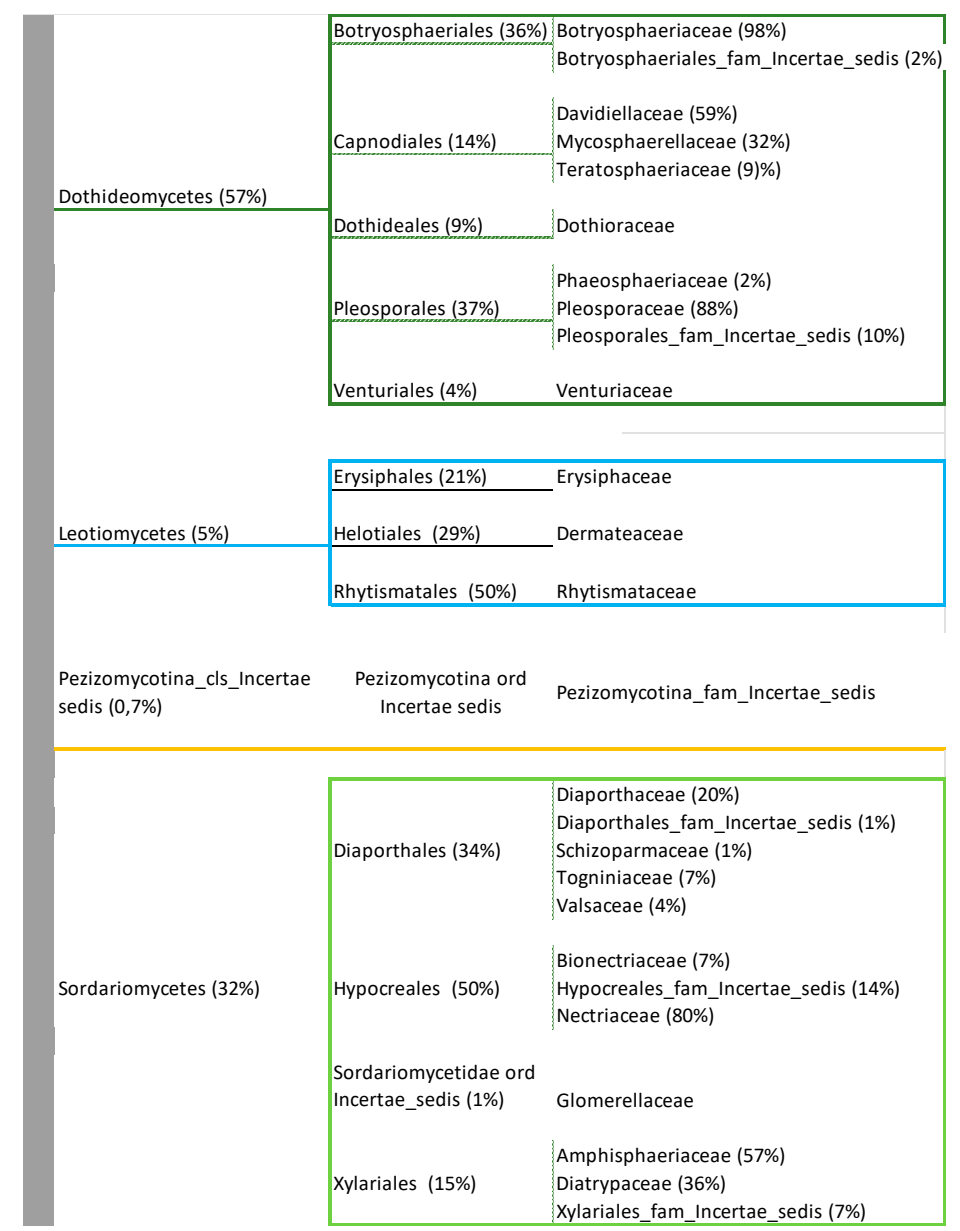

Figure 3. Relative abundance of different taxonomic groups within the Ascomycota of OTUs classified as plant pathogens.

The class Dothideomycetes (57\%) was the most abundant and consisted of fungal sequences in the orders Botryosphaeriales (36\%), Capnodiales (14\%), Dothideales (9\%), Pleosporales (37\%) and Venturiales (4\%). The phylum Basidiomycota accounted for $5 \%$ of the plant pathogens sequences identified at the species level. It included Agaricomycetes (43\%), with only Mycenaceae, and Exobasidiomycetes (57\%), dominated by Exobasidiaceae (75\%), followed by Quambalariaceae ( $25 \%)$.

A NMDS biplot revealed that the fungal community differed among samples. Pinus species and country of origin were not related to the fungal community (Figure 4). For example, fungal communities from P. sylvestris (Ps10, Ps11 and Ps12 from Sweden, Ps13 from USA, Ps5 from Turkey and Ps23 from Portugal) did not cluster together.

Plant pathogen SpOTUs grouped as 141 different species, of which 35\% have been associated to Pinus species from all over the world. Among those species, Pestalotiopsis microspora was never recorded in Europe [47]. However, it was detected on samples of $P$. brutia (P3) and P. radiata (P6) from Turkey and P. radiata (P24) from Portugal. Pinus radiata was associated with more than $55 \%$ of pine pathogens. The double hierarchical dendrogram shows the fungal community distribution with more than $10 \%$ of taxa in seed samples (Figure 5). Most of the SpOTUs were identified as Sydowia polyspora 
(31\%), Lasiodiplodia theobromae (13\%), Diplodia intermedia (12\%) and Diplodia sapinea (18\%), which were the most abundant species found, representing over $10 \%$ of all SpOTUs $(n=276)$. These species were present in all samples, except Ps13 and Ps5. Sequence data for the four most dominant fungal species were deposited in GenBank (Accessions MK635056-MK635059).

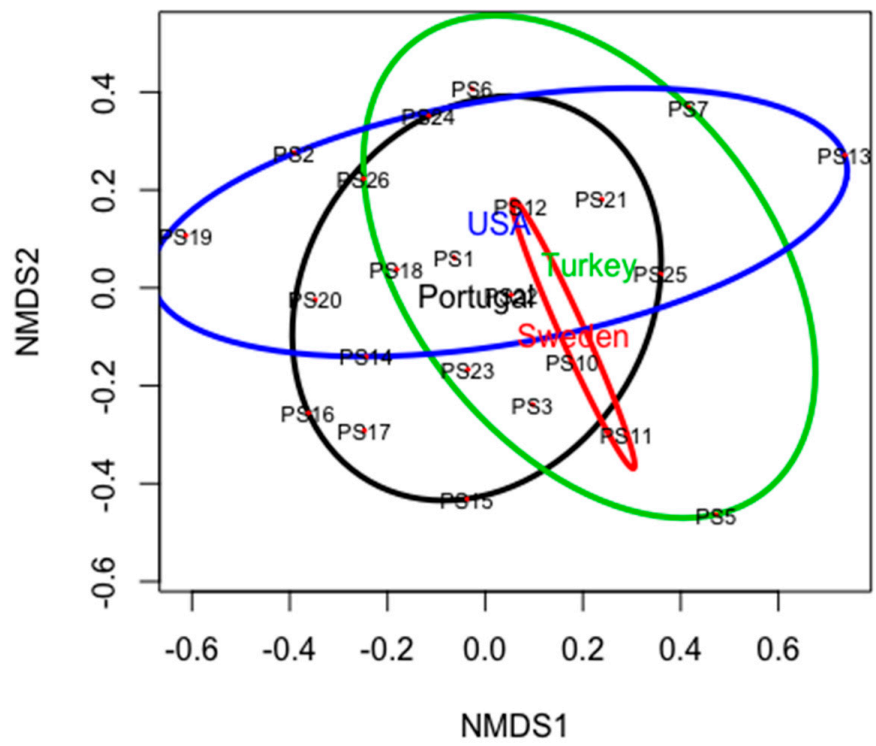

Figure 4. Two-dimensional non-metric multidimensional scaling (NMDS) biplots based on Bray-Curtis distances displaying differences among the fungal community structures identified to the species level. The points represent Pinus samples (see sample ID, Table 1). The coloured ellipses represent the country of the samples' origin. $R^{2}=0.95$.

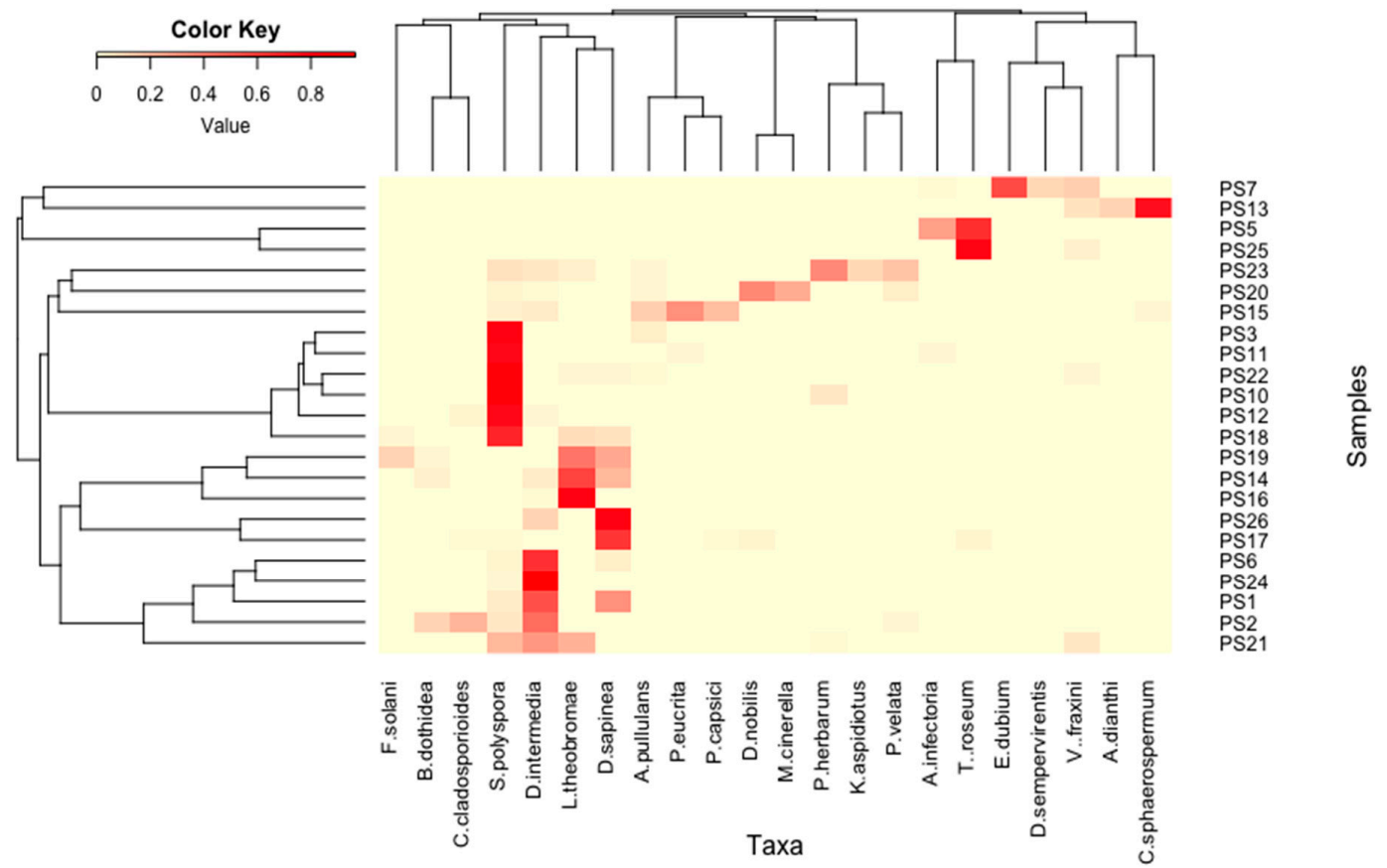

Figure 5. Heatmap analysis of identified pathogenic fungi that represented more than $10 \%$ of taxa detected in seed samples. Numbers indicate the samples of Pinus species seed (Table 1).

A phylogenetic tree was built to confirm the identity of four SpOTUs (C202, C607, C333 and C625), namely S. polyspora, L. theobromae, D. intermedia and D. sapinea, in relation to other taxa (Figure 6). Diplodia intermedia and D. sapinea clustered together. Lasiodiplodia species could not be resolved based 
on analysis of a portion of the ITS region. Sequences of S. polyspora were placed in a distinct clade separate from all other species and supported by a high bootstrap value (Figure 6).

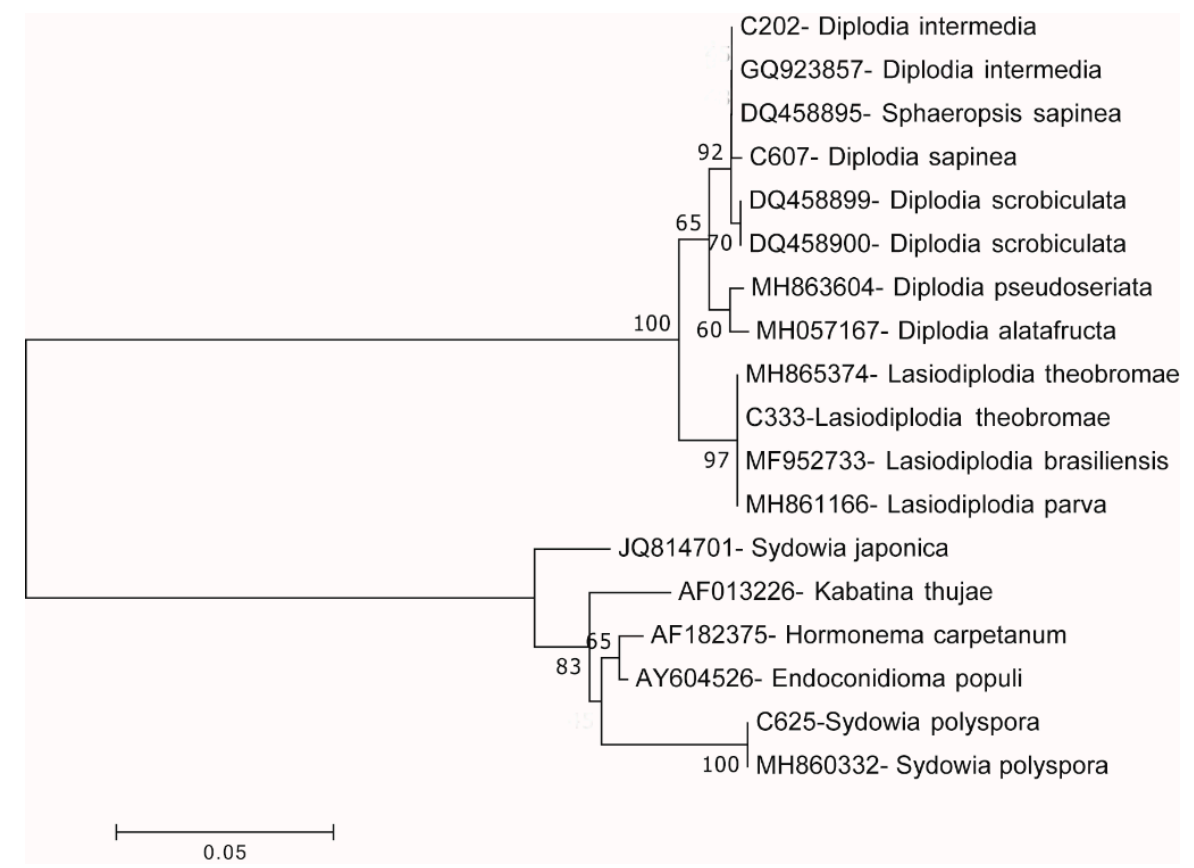

Figure 6. Neighbour joining phylogenetic tree based on the ITS region showing the position of SpOTUs C202, C607, C333 and C625 in relation to other taxa. Bootstrap support values (percentages of 1000 replicates) are shown on branches (values, $50 \%$ are not shown).

\section{Discussion}

The fungal communities present in seeds of a variety of Pinus species obtained from commercial outlets were examined using HTS in order to assess the presence of known plant pathogens and the potential risk of introduction through the trade of seeds. Identification of nearly 2000 OTUs confirmed diverse fungal communities in or on seeds of different Pinus species. Fungi that were commonly detected and identified were polyphagous, often occurring in several Pinus species, however communities were not structured by host or source origin (country). Replicates of the same Pinus species in this study (P. sylvestris, P. pinaster, P. radiata, and P. pinea), harbored distinguishable fungal communities, perhaps with the exception of the Swedish seedlots. Species accumulation curves showed that sampling effort in individual seedlots adequately represented the diversity present in these fungal communities.

Many of the fungi associated with the seed tend to have saprotrophic lifestyles and are unlikely to have a significant impact on seed germination and seedling growth [48-50]. However, a significant proportion of the OTUs detected were potential pathogens that could cause seed damage, seedling diseases (damping-off), and shoot and tip dieback diseases of older pine trees. However, none of the species identified are included in the European Plant Protection Organization (EPPO) A1 and A2 quarantine lists.

In this study we used the ITS region which is generally accepted as the official barcode for fungi by several mycologists due to its ease in amplification, widespread use, and appropriately large barcode gap [51]. However, there are limitations to the use of ITS as a standard for molecular identification because intraspecific variation does not permit sufficient resolution for the identification of some fungal species. In addition, the $97 \%$ sequence similarity threshold for the ITS marker gene can be too conservative for species-level identification of some fungal taxa [32]. Specifically, the genera Fusarium and Diaporthe are known to contain species complexes [52,53]. At least ten putative Fusarium taxa were detected in this study using ITS sequencing (Supplementary File 1), though further work would 
be needed using additional and specific markers [54] to resolve the Fusarium species identification. A phylogenetic approach helped resolve some limitations to the barcoding for the identification of dominant plant pathogens in this study, namely, S. polyspora, L. theobromae, D. intermedia and D. sapinea which were identified in multiple Pinus species.

Sydowia polyspora is commonly known as a foliar endophyte and a weak, opportunistic pathogen that under certain conditions can cause small foliar lesions [55]. Current year needle necrosis caused by S. polyspora has been associated with true fir (Abies spp.) across Europe and North America [56-59]. The recent finding of $S$. polyspora behaving as a cryptic pathogen strongly delaying seed emergence in Pinus ponderosa [60] supports the idea that fungi may have a broad repertoire of ecological interactions with their hosts that may include the ability to infect and colonize them with and without causing visible damage. Although common foliar endophytes such as S. polyspora can become opportunistic pathogens, attacking hosts under conditions conducive to fungal growth, this problem may become more relevant with climate change as additional stresses are added to host growing conditions. A better understanding of the dynamics of fungal life strategies working either positively or negatively on the host, and in some cases cryptically in plant community processes, is needed [60].

Lasiodiplodia theobromae is a fungus that causes black seed rot, resulting in the destruction of slash pine (Pinus elliottii var. elliottii) seeds in southern USA and shoot dieback of slash and loblolly (P. taeda) pine seedlings in nurseries [61,62]. Lasiodiplodia theobromae is a cosmopolitan, polyphagous, and opportunistic fungal pathogen on a variety of woody hosts across the globe [63]. The pathogen has been detected in seed of P. caribaea, P. oocarpa in Central America [64,65], P. elliottii in South Africa and southeastern USA [6,61,66] and recently in P. elliottii and P. taeda in Brazil [7]. Its presence inside the seed impairs germination and causes seedling death. A diverse mycoflora including L. theobromae, Fusarium spp. and D. sapinea was associated with slash pine (P. elliottii var. elliottii) seeds obtained from a seed orchard and cone-processing facility in southeastern USA [66]. Cone collection practices can influence the incidence of disease since Fraedrich et al. [8] found that seeds from cones removed prematurely from trees and left on the ground for short periods had higher infection levels and contamination by L. theobromae than seeds from cones that were close to maturation at the time of collection.

Diplodia sapinea is one of the more economically important damaging agents of Pinus species worldwide, occasionally affecting other important conifers such as Pseudotsuga sp. Abies sp., Picea sp. and Larix sp. [67]. Severe epidemics have been reported from pine nurseries and plantations in North America [68,69] and more recently in the Baltic and Scandinavian region [9,70]. Diplodia sapinea has been detected in seed from several Pinus species all around the globe $[8,10,65,66,71-79]$, and can remain alive in seed for several years [10]. Decourcelle et al. [10] showed a high percentage of infections in the seeds of Corsican pine trees having no apparent symptoms of $D$. sapinea. It is well known that latent infections exist in symptomless tissue on both diseased and non-diseased trees, and have the potential to become pathogenic [74,80,81]. Although Decourcelle et al. [10] found the risk of disease transmission was low in Corsican pine seeds, the frequent importation and use of latently infected pine seed has been implicated as a factor promoting the global movement of $D$. sapinea. A higher genetic diversity in South African populations of $D$. sapinea compared to other southern hemisphere countries was linked to historical records of the frequency and quantity of seed and germplasm importation $[82,83]$. An added risk with multiple introductions is the possibility of new introduced genotypes that may cross with existing genotypes, allowing for more gene diversity and possibly greater pathogen virulence, leading to more severe disease outbreaks [19]. Thus, the possibility cannot be excluded that seed contamination originating from seed orchards-often the main suppliers of large seed quantities to forest tree nurseries for reforestation efforts-accidentally plays a role in the dissemination of this pathogen to unaffected regions.

Pestalotiopsis microspora was the only species associated with Pinus species not yet present in Europe. The fungus has been detected as an endophyte on Pinus radiata in Kenya and as a pathogen on several fruits, e.g., kiwi, outside Europe [47]. The introduction of P. microspora could pose a risk for 
European cultivations. An earlier introduction of a closely related species, P. maculans, now established in Spain, was also attributed to seed [4].

A large majority (approximately 65\%) of the plant pathogens identified were not associated to Pinus species but rather to other plant hosts. Among these were cosmopolitan, polyhagous plant pathogens such as Botryosphaeria stevensii, B. dothidea, Neofusicoccum parvum, and several species of Fusarium (teleomorph Gibberella) and Diaporthe that are yet unresolved. Pathogens having relatively restricted host range such as Valsa sordida - commonly associated to poplar, Eutypa lata - the causal agent of Dead arm of grapevine, and Ramularia eucalypti, a common leaf spot disease of Eucalyptus hosts, were also detected in Pinus species seeds. The results suggest that seed transported for commercial use can be subjected to contamination by propagules of a large diversity of fungi including obvious influences by the external environment to which that commercial seed is cultivated, collected or processed. This raises further questions as to whether there would be a potential for introducing crop pathogens via seed of highly unrelated ornamental species, or vice versa.

Increased knowledge of the mycobiome associated with seeds, including the identification of potentially harmful pathogens, is needed to make informed decisions prior to transport or regarding phytosanitary measures to prevent the introduction and establishment of invasive pathogens. For example, previous detection of the alien invasive fungus Hymenoscyphus fraxineus on seeds of Fraxinus excelsior [84] supported phytosanitary measures in North America and the UK to prohibit the import, and in the case of the UK, the internal movement of plant material including seeds. Even though $H$. fraxineus does not appear to be a seed-borne disease [85], infested seed still serve as a potential source of inoculum capable of forming ascomata, and subsequent sporulation under optimal temperature and moisture conditions. For most seed-borne fungi, populations can increase during phases of seed development, seed harvesting and processing, especially under high moisture and temperature conditions which are conducive to their development [86].

Seed fungi are found on and in the seedcoat and in the gametophyte and embryo, and with the exception of molds, are not easily detected through visual observation [86]. Even seedlots infested with known pathogens appear normal and healthy-looking [84]. As in this study, the Pinus species seedlots utilized contained multiple plant pathogens but appeared healthy and viable, and undoubtedly would pass a visual phytosanitary inspection. However, the symptomless persistence of the identified pathogens such as D. sapinea and S. polyspora could have important implications for dissemination and emergence of new disease outbreaks. Even superficial contamination can affect seed germination and subsequent seedling damage at a later stage [14], although the thresholds are not well known. Moreover, only a fraction of the total taxa detected were identified, thus it is reasonable that there may be other pathogens not yet discovered.

Anonymity and transporting seed from 'unknown' locations such as those acquired from online distributors provides an added element of risk for introducing invasive species since it is not known what potential pathogens are carried in or on the seed. We strongly encourage seed production and retail distributors to adopt better biosecurity practices: the mycobiota associated with the commercial seedlots they are selling should be known, and the shipment of seeds containing potentially pathogenic fungi should be avoided. At the very least, measures must be taken to reduce or eliminate the risk by appropriate seed treatment (e.g., thermotherapy). Consumers need to adopt socially and environmentally responsible consumer behavior when purchasing commercial seed, requesting basic information on source location of the seed (as opposed to geographic origin of the species), and purchase locally to deter the possible entry of new invasive threats. In the EU, the European directive for the marketing of forest reproductive material only mentions that imports of tree seed consignments from suppliers should comply with species purity and germination capacity [87]. Moreover, the European directive on protective measures against the introduction of organisms harmful to plant or plants products and against their spread within, with the exception of Pinus species and P. menziesii [18], mainly excludes seeds of woody plants from controls during import from non-European countries [88]. Plant protection authorities should however be alerted to the potential risk associated with import and 
domestic movement of seeds and consider phytosanitary measures to minimize the risk of introducing not just quarantine, but other potentially harmful and emerging pathogens.

The study highlights several known pathogenic fungi, and possible cryptic risks associated with the intra- and intercontinental movement of tree seed for commercial, including ornamental, purposes. The use of HTS technologies for screening biosecurity risks remains underutilized in practice. For Pinus — which has such a large economic importance globally—the risk of disseminating pathogens (including those causing serious foliar and shoot diseases) through the transport of seeds, is certain. This work, together with evidence from numerous studies $[2,4,15,19]$ and cases added to the curated database for Europe [4] since 2013 such as Neonectria neomacrospora and Sirococcus tsugae (Alberto Santini, personal communication, 13 May 2019) lend strong support to the argument that seed distribution for commercial purposes can contribute to the etiology of several emerging forest diseases.

Supplementary Materials: The following are available online at http://www.mdpi.com/1999-4907/10/5/459/s1. Supplementary File 1, Table S1: Relative abundances of OTU sequences in different Pinus spp. from different countries (Turkey, Sweden, USA and Portugal).

Author Contributions: Author contributions can be summarized as follows: conceptualization, S.W. and A.M.V.; methodology and laboratory work, M.C., F.O., and A.M.V.; supervision, M.C.; project administration, M.C.; bioinformatics and statistical analysis, A.M.V.; data curation, F.O. and A.M.V.; writing-original draft preparation, M.C., A.M.V., and S.W.; writing - review and editing, M.C., S.W., and A.M.V., supplemented with comments from F.O., H.T.D., and A.L.; and funding acquisition, M.C.

Funding: This research was funded by the Swedish Research Council FORMAS grant number 2018-00966, and the UK Forestry Commission. Support was also provided by the EU-COST Action FP 1406 "Pine pitch canker-strategies for management of Gibberella circinata in greenhouses and forests" (PINESTRENGTH).

Acknowledgments: We gratefully acknowledge laboratory support from Mohammed Elsafy, and the Forest Tree Seeds and Tree Breeding Research Directorate, for providing the Turkish seeds. We gratefully acknowledge Alberto Santini from the Institute for Sustainable Plant Protection-C.N.R. in Italy for providing information on documented seed introductions to Europe from the international database he maintains.

Conflicts of Interest: The authors declare no conflict of interest. The funders had no role in the design of the study; in the collection, analyses, or interpretation of data; in the writing of the manuscript; or in the decision to publish the results.

\section{References}

1. Roques, A. Alien forest insects in a warmer world and a globalised economy: Impacts of changes in trade, tourism and climate on forest biosecurity. N. Z. J. For. Sci. 2010, 40, 77-94.

2. Jimu, L.; Kemler, M.; Wingfield, M.J.; Mwenje, E.; Roux, J. The Eucalyptus stem canker pathogen Teratosphaeria zuluensis detected in seed samples. Forestry 2016, 89, 316-324. [CrossRef]

3. Jaynes, R.A.; DePalma, N.K. Natural infection of nuts of Castanea dentata by Endothia parasitica. Phytopathology 1984, 74, 296-299. [CrossRef]

4. Santini, A.; Ghelardini, L.; Pace, C.; Desprez-Loustau, M.L.; Capretti, P.; Chandelier, A.; Cech, T.; Chira, D.; Diamandis, S.; Gaitniekis, T.; et al. Biogeographical patterns and determinants of invasion by forest pathogens in Europe. New Phytol. 2013, 197, 238-250. [CrossRef] [PubMed]

5. Woods, T.A.D.; Farris, S.H.; Sutherland, J.R. Penetration of Sitka spruce seeds by the pathogenic fungus Caloscypha fulgens. Can. J. Bot. 1982, 60, 544-548. [CrossRef]

6. Cilliers, A.J.; Swart, W.J.; Wingfield, M.J. The occurrence of Lasiodiplodia theobromae on Pinus elliottii seeds in South Africa. Seed Sc. Technol. 1995, 23, 851-860.

7. Maciel, C.G.; Muniz, M.F.B.; Mezzomo, R.; Reiniger, L.R.S. Lasiodiplodia theobromae associated with seeds of Pinus spp. originated from the northwest of Rio Grande do Sul, Brazil. Sci. For./For. Sci. 2015, 43, 639-646.

8. Fraedrich, S.W.; Miller, T.; Zarnoch, S.J. Factors affecting the incidence of black seed rot in slash pine. Can. J. For. Res. 1994, 24, 1717-1725. [CrossRef]

9. Adamson, K.; Klavina, D.; Drenkhan, R.; Gaitnieks, T.; Hanso, M. Diplodia sapinea is colonizing the native Scots pine (Pinus sylvestris) in the northern Baltics. Eur. J. Plant Pathol. 2015, 143, 343-350. [CrossRef]

10. Decourcelle, T.; Piou, D.; Desprez-Loustau, M.L. Detection of Diplodia sapinea in Corsican pine seeds. Plant Pathol. 2015, 64, 442-449. [CrossRef] 
11. Oliva, J.; Boberg, J.; Stenlid, J. First report of Sphaeropsis sapinea on Scots pine (Pinus sylvestris) and Austrian pine (P. nigra) in Sweden. New Dis. Rep. 2013, 27, 23. [CrossRef]

12. Viljoen, A.; Wingfield, M.J.; Maras, W.F.O. First report of Fusarium subglutians f. sp. pini on pine seedlings in South Africa. Plant Dis. 1994, 78, 309-312.

13. Wingfield, M.J.; Hammerbacher, A.; Ganley, R.J.; Steenkamp, E.T.; Gordon, T.R.; Wingfield, B.D.; Coutinho, T.A. Pitch canker caused by Fusarium circinatum-A growing threat to pine plantations and forests worldwide. Australas. Plant Pathol. 2008, 37, 319-334. [CrossRef]

14. Dwinell, L.D. Contamination of Pinus radiata Seeds in California by Fusarium circinatum. In Proceedings of the Annual International Research Conference on Methyl Bromide Alternatives and Emissions Reductions, San Diego, CA, USA, 1-4 November 1999; pp. 1-3.

15. Storer, A.J.; Gordon, T.R.; Clarck, S.L. Association of the pitch canker fungus, Fusarium subglutinans f. sp. pini with Monterey pine seeds, and seedlings in California. Plant Pathol. 1998, 47, 649-656.

16. EFSA, P.L.H. Panel (EFSA Panel on Plant Health). PLH Guidance on a harmonised framework for pest risk assessment and the identification and evaluation of pest risk management options by EFSA. EFSA J. 2010, $8,1495$.

17. Gordon, T.R.; Kirkpatrick, S.C.; Aegerter, B.J.; Wood, D.L.; Storer, A.J. Susceptibility of Douglas fir (Pseudotsuga menziesii) to pitch canker, caused by Gibberella circinata (anamorph $=$ Fusarium circinatum). Plant Pathol. 2006, 55, 231-237. [CrossRef]

18. Vettraino, A.M.; Potting, R.; Raposo, R. EU legislation on forest plant health: An overview with a focus on Fusarium circinatum. Forests 2018, 9, 568. [CrossRef]

19. Burgess, T.; Wingfield, M.J. Quarantine is important in restricting the spread of exotic seed-borne tree pathogens in the southern hemisphere. Int. For. Rev. 2002, 4, 56-65.

20. Bentele, M.; Morgenstern, K.; Krabel, D. Lophodermium seditiosum Minter, Staley \& Millar seed-borne on Pinus sylvestris. J. For. Landsc. Res. 2014, 1, 1-8.

21. Morgenstern, K.; Döring, M.; Krabel, D. Rhabdocline needle cast-Most recent findings of the occurrence of Rhabdocline pseudotsugae in Douglas-fir seeds. Botany 2014, 92, 465-469. [CrossRef]

22. Morgenstern, K.; Döring, M.; Krabel, D. Rhabdocline needle cast-Investigations on various Douglas fir tissue types. Eur. J. Plant Pathol. 2013, 137, 495-504. [CrossRef]

23. Hibbett, D.S.; Ohman, A.; Kirk, P.M. Fungal ecology catches fire. New Phytol. 2009, 184, 279-282. [CrossRef] [PubMed]

24. Hibbett, D.; Abarenkov, K.; Kõljalg, U.; Öpik, M.; Chai, B.; Cole, J.; Wang, Q.; Crous, P.; Robert, V.; Helgason, T.; et al. Sequence-based classification and identification of Fungi. Mycologia 2016, 108, 1049-1068.

25. Hawksworth, D.L.; Lücking, R. Fungal diversity revisited: 2.2 to 3.8 million species. Microbiol. Spectr. 2017, 5. [CrossRef]

26. Nilsson, R.H.; Anslan, S.; Bahram, M.; Wurzbacher, C.; Baldrian, P.; Tedersoo, L. Mycobiome diversity: High-throughput sequencing and identification of fungi. Nat. Rev. Microbiol. 2019, 17, 95-109. [CrossRef] [PubMed]

27. Tremblay, E.D.; Duceppe, M.O.; Berube, J.A.; Kimoto, T.; Lemieux, C.; Bilodeau, G.J. Screening for exotic forest pathogens to increase survey capacity using metagenomics. Phytopathology 2018, 108, 1509-1521. [CrossRef] [PubMed]

28. Tremblay, É.D.; Kimoto, T.; Bérubé, J.A.; Bilodeau, G.J. Next-generation sequencing to investigate existing and new insect associations with phytopathogenic fungal propagules. J. Fungi. 2019, 5, 15. [CrossRef] [PubMed]

29. Berubé, J.A.; Gagné, P.N.; Ponchart, J.P.; Tremblay, É.D.; Bilodeau, G.J. Detection of Diplodia corticola spores in Ontario and Québec based on High Throughput Sequencing (HTS) methods. Can. J. Plant Pathol. 2018, 40, 378-386. [CrossRef]

30. Abdelfattah, A.; Malacrinò, A.; Wisniewski, M.; Cacciola, S.O.; Schena, L. Metabarcoding: A powerful tool to investigate microbial communities and shape future plant protection strategies. Biol. Cont. 2018, 120, 1-10. [CrossRef]

31. Bulman, S.R.; McDougal, R.L.; Hill, K.; Lear, G. Opportunities and limitations for DNA metabarcoding in Australasian plant-pathogen biosecurity. Australas. Plant Pathol. 2018, 47, 467-474. [CrossRef] 
32. Tedersoo, L.; Drenkhan, R.; Anslan, S.; Morales-Rodriguez, C.; Cleary, M. High-throughput identification and diagnostics of pathogens and pests: Overview and practical recommendations. Mol. Ecol. Resour. 2019, 19, 47-76. [CrossRef]

33. Adams, I.P.; Fox, A.; Boonham, N.; Massart, S.; De Jonghe, K. The impact of high throughput sequencing on plant health diagnostics. Eur. J. Plant Pathol. 2018, 152, 909-919. [CrossRef]

34. Vettraino, A.; Roques, A.; Yart, A.; Fan, J.T.; Sun, J.H.; Vannini, A. Sentinel Trees as a Tool to Forecast Invasions of Alien Plant Pathogens. PLoS ONE 2015, 10, e0120571. [CrossRef]

35. Vettraino, A.M.; Li, H.M.; Eschen, R.; Morales-Rodriguez, C.; Vannini, A. The sentinel tree nursery as an early warning system for pathway risk assessment: Fungal pathogens associated with Chinese woody plants commonly shipped to Europe. PLoS ONE 2017, 12, e0188800. [CrossRef]

36. Eschen, R.; Douma, J.C.; Grégoire, J.C.; Mayer, F.; Rigaux, L.; Potting, R.P.J. A risk categorisation and analysis of the geographic and temporal dynamics of the European import of plants for planting. Biol. Invasions. 2017, 19, 3243-3257. [CrossRef]

37. Vega, D.; Gally, M.E.; Romero, A.M.; Poggio, S.L. Functional groups of plant pathogens in agroecosystems: A review. Eur. J. Plant Pathol. 2019, 153, 695-713. [CrossRef]

38. Auger-Rozenberg, M.A.; Roques, A. Seed wasp invasions promoted by unregulated seed trade affect vegetal and animal biodiversity. Integr. Zool 2012, 7, 228-246. [CrossRef]

39. White, T.J.; Bruns, T.; Lee, S.; Taylor, J. Amplification and direct sequencing of fungal ribosomal RNA genes for phylonetics. In PCR Protocols: A Guide to Methods and Applications; Innis, M.A., Gelfand, D.H., Sninsky, J.J., White, T.J., Eds.; Academic Press: New York, NY, USA, 1990; pp. 315-322.

40. Ihrmark, K.; Bödeker, I.T.M.; Cruz-Martinez, K.; Friberg, H.; Kubartova, A.; Schenck, J.; Strid, Y.; Stenlid, J.; Brandström-Durling, M.; Clemmensen, K.E.; et al. New primers to amplify the fungal ITS2 region-Evaluation by 454-sequencing of artificial and natural communities. FEMS Microbiol. Ecol. 2012, 82, 666-677. [CrossRef]

41. Caporaso, J.G.; Kuczynski, J.; Stombaugh, J.; Bittinger, K.; Bushman, F.D.; Costello, E.K.; Fierer, N.; Peña, A.G.; Goodrich, J.K.; Gordon, J.I.; et al. QIIME allows analysis of high-throughput community sequencing data. Nat. Methods 2010, 7, 335-336. [CrossRef]

42. Nguyen, N.H.; Song, Z.; Bates, S.T.; Branco, S.; Tedersoo, L.; Menke, J.; Schilling, J.S.; Kennedy, P.G. FUNGuild: An open annotation tool for parsing fungal community datasets by ecological guild. Fungal Ecol. 2016, 20, 241-248. [CrossRef]

43. Oksanen, F.G.B.; Friendly, M.; Kindt, R.; Legendre, P.; McGlinn, D.; Minchin, P.R.; O’Hara, R.B.; Simpson, G.L.; Solymos, P.; Stevens, M.H.H.; et al. Community Ecology Package. R Package. 2016. Available online: https://CRAN.R-project.org/package=vegan (accessed on 23 July 2018).

44. Thompson, J.D.; Higgins, D.G.; Gibson, T.J. CLUSTAL W: Improving the sensitivity of progressive multiple sequence alignment through sequence weighting, position-specific gap penalties and weight matrix choice. Nucleic Acids Res. 1994, 22, 4673-4680. [CrossRef]

45. Felsenstein, J.P. Phylogeny inference package (version 32). Cladistics 1989, 5, 164-166.

46. Page RDM. TreeView version 166 Glasgow: University of Glasgow. 2001. Available online: http://taxonomy. zoology.gla.ac.uk/ROD/treeview.html (accessed on 23 July 2018).

47. Farr, D.F.; Rossman, A.Y. Fungal Databases, U.S. National Fungus Collections, ARS, USDA. Available online: https://nt.ars-grin.gov/fungaldatabases/ (accessed on 29 April 2019).

48. Anderson, R.L. Checklist of micro-organisms associated with tree seeds in the world. Gen. Tech. Rep. 1986, 39,34 .

49. Mittal, R.K.; Wang, B.S.P. Fungi associated with seeds of eastern white pine and white spruce during cone processing and seed extraction. Can. J. For. Res. 1987, 17, 1026-1034. [CrossRef]

50. Mittal, R.K.; Anderson, R.L.; Mathur, S.B. Microorganisms Associated with Tree Seeds: World Checklist 1990; Forestry Canada, Petawawa National Forestry Institute: Chalk River, ON, Canada, 1990; 70p.

51. Schoch, C.L.; Seifert, K.A.; Huhndorf, S.; Robert, V.; Spouge, J.L.; Levesque, C.A.; Fungal Barcoding Consortium. Nuclear ribosomal internal transcribed spacer (ITS) region as a universal DNA barcode marker for Fungi. Proc. Natl. Acad. Sci. USA 2012, 109, 6241-6246. [CrossRef] [PubMed]

52. Chehri, K.; Salleh, B.; Zakaria, L. Morphological and phylogenetic analysis of Fusarium solani species complex in Malaysia. Microb. Ecol. 2014, 69, 457-471. [CrossRef]

53. Udayanga, D.; Castlebury, L.A.; Rossman, A.Y.; Chukeatirote, E.; Hyde, K.D. Insights into the genus Diaporthe: Phylogenetic species delimitation in the D. eres species complex. Fungal Divers. 2014, 67, 203-229. [CrossRef] 
54. Karlsson, I.; Edel-Hermann, V.; Gautheron, N.; Durling, M.B.; Kolseth, A.K.; Steinberg, C.; Persson, P.; Friberg, H. Genus-specific primers for study of Fusarium communities in field samples. Appl. Environ. Microbiol. 2016, 82, 491-501. [CrossRef]

55. Funk, A. Foliar Fungi of Western Trees; Agriculture Canada, Ministry of State for Forestry, Pacific forest Research Centre: Victoria, BC, Canada, 1985; 159p.

56. Thomsen, I.M. Current season needle necrosis (CSNN) in Denmark Working Papers. In Proceedings of the 8th International Christmas Tree Research and Extension Conference, Bogense, Denmark, 12-18 August 2007; Thomsen, I.M., Rasmussen, H.N., Sørensen, J.M., Eds.; Forest \& Landscape Denmark: Hørsholm, Denmark, 2008; pp. 88-91.

57. Talgø, V.; Chastagner, G.A.; Thomsen, I.M.; Cech, T.; Lange, K.; Riley, K.; Perny, B.; Klemsdal, S.S.; Stensvand, A. Sydowia polyspora associated with current season needle necrosis (CSNN) on true fir (Abies spp.). Fungal Biol. 2010, 114, 545-554. [CrossRef]

58. Chastagner, G.A.; Staley, J.M.; Riley, K.L. Current season needle necrosis: A needle disorder of unknown etiology on noble and grand fir Christmas trees in the Pacific Northwest. In Recent Research on Foliage Diseases, Conference Proceedings; Merrill, W., Ostry, M.E., Eds.; General Technical Reports; USDA Forest Service: Washington, DC, USA, 1990; pp. 38-42.

59. Chastagner, G.A.; Riley, K. Diseases that limit the production of noble fir Christmas trees in the Pacific Northwest. Skov \& Landskab Report No. 7. In Improvements in Christmas Tree and Greenery Quality; Christensen, C.J., Ed.; Danish Center for Forest, Landscape and Planning: Horsholm, Denmark, 2000; pp. 13-21.

60. Ridout, M.; Newcombe, G. Sydowia polyspora is both a foliar endophyte and a preemergent seed pathogen in Pinus ponderosa. Plant Dis. 2018, 102, 640-644. [CrossRef]

61. Cram, M.M.; Fraedrich, S.W. Seed diseases and seedborne pathogens of North America. Tree Plant. Notes 2010, 53, 35-44.

62. Rowan, S.J. Tip dieback in southern pine nurseries. Plant Dis. 1982, 66, 258-259. [CrossRef]

63. Punithalingam, E. Plant Diseases Attributed to Botryodiplodia Theobromae Pat; J. Cramer: Vaduz, Lichtenstein, 1980.

64. Rees, A.A. Infection of Pinus caribaea seed by Lasiodiplodia theobromae. Trans. Br. Mycol. Soc. 1988, 90, 321-324. [CrossRef]

65. Rees, A.A.; Webber, J.F. Pathogenicity of Sphaeropsis sapinea to seed seedlings and saplings of some Central American pines. Trans. Br. Mycol. Soc. 1998, 91, 273-277. [CrossRef]

66. Fraedrich, S.W.; Miller, T. Mycoflora associated with slash-pine seeds from cones collected at seed orchards and cone-processing facilities in the south-eastern USA. Eur. J. For. Pathol. 1995, 25, 73-82. [CrossRef]

67. Sinclair, W.A.; Lyon, H.H. Diseases of Trees and Shrubs, 2nd ed.; Cornell University Press: Ithaca, NY, USA, 2005.

68. Stanosz, G.R.; Blodgett, J.T.; Smith, D.R.; Kruger, E.L. Water stress and Sphaeropsis sapinea as a latent pathogen of red pine seedlings. New Phytol. 2001, 149, 531-538. [CrossRef]

69. Stanosz, G.R.; Smith, D.R.; Leisso, R. Diplodia shoot blight and asymptomatic persistence of Diplodia pinea on or in stems of jackpine nursery seedlings. For. Pathol. 2007, 37, 145-154. [CrossRef]

70. Brodde, L.; Adamson, K.; Camarero, J.J.; Castaño, C.; Drenkhan, R.; Lehtijärvi, A.; Luchi, N.; Migliorini, D.; Sánchez-Miranda, Á.; Stenlid, J.; et al. Diplodia Tip Blight on Its Way to the North: Drivers of Disease Emergence in Northern Europe. Front. Plant Sci. 2019, 9, 1818. [CrossRef]

71. Zakaullah, A.F. Mycoflora associated with blue pine seed. Pak. J. For. 2000, 50, 25-31.

72. Bihon, W.; Slippers, B.; Burgess, T.; Wingfield, M.J.; Wingfield, B.D. Sources of Diplodia pinea endophytic infections in Pinus patula and P. radiata seedlings in South Africa. For. Pathol. 2011, 41, 370-375. [CrossRef]

73. Dwinell, L.D. Association of the pitch canker fungus with cones and seeds of pines. In Current and Potential Impacts of Pitch Canker in Radiata Pine. Proc. CSIRO, Australia, 30 November-3 December 1998; Devey, M.E., Matheson, A.C., Gordon, T.R., Eds.; IMPACT Monterey Workshop: Monterey, CA, USA, 1999; pp. 35-39.

74. Flowers, J.; Nuckles, E.; Hartman, J.; Vaillancourt, L. Latent infection of Austrian and Scots pine tissues by Sphaeropsis sapinea. Plant Dis. 2001, 85, 1107-1112. [CrossRef]

75. Iturritxa, E.; Desprez-Loustau, M.L.; Garcia-Serna, I.; Quintana, E.; Mesanza, N.; Atkiens, J. Effect of alternative disinfection treatments against fungal canker in seeds of Pinus radiata. Seed Tech. 2011, 33, 88-110. 
76. Romero, G. Relationship of seed-borne pathogens to nursery and plantation diseases of eucalypts and pines in Uruguay. In Proceedings of the ISTA Tree Seed Pathology Meeting, Opocno, Czech Republic, 9-11 October 1996; Prochazkova, Z., Sutherland, J.R., Eds.; International Seed Testing Association: Zurich, Switzerland, 1997; pp. 82-85.

77. Smith, H.; Wingfield, M.J.; Crous, P.W.; Coutinho, T.A. Sphaeropsis sapinea and Botryosphaeria dothidea endophytic in Pinus spp. and Eucalyptus spp. in South Africa. S. Afr. J. Bot. 1996, 62, 86-88. [CrossRef]

78. Smith, H.; Wingfied, M.J.; Coutinho, T.A. The role of latent Sphaeropsis sapinea infections in post-hail associated die-back of Pinus patula. For. Ecol. Manag. 2002, 164, 177-184. [CrossRef]

79. Vujanovic, V.; St-Arnaud, M.; Neumann, P.J. Susceptibility of cones and seeds to fungal infection in a pine (Pinus spp.) collection. For. Pathol. 2000, 30, 305-320. [CrossRef]

80. Stanosz, G.R.; Smith, D.R.; Guthmller, M.A.; Stanosz, J.C. Persistence of Sphaeropsis sapinea on or in asymptomatic shoots of red and jack pines. Mycologia 1997, 89, 525-530. [CrossRef]

81. Slippers, B.; Wingfield, M.J. The Botryosphaeriaceae as endophytes and latent pathogens of trees: Identification, ecology and potential impact. Fungal Biol. Rev. 2007, 21, 90-106. [CrossRef]

82. Smith, H.; Wingfield, M.J.; de Wet, J.; Coutinho, T.A. Genotypic Diversity of Sphaeropsis sapinea from South Africa and Northern Sumatra. Plant Dis. 2000, 84, 139-142. [CrossRef]

83. Burgess, T.; Wingfield, B.D.; Wingfield, M.J. Comparison of genotypic diversity in native and introduced populations of Sphaeropsis sapinea isolated from Pinus radiata. Mycol. Res. 2001, 105, 133-1339. [CrossRef]

84. Cleary, M.R.; Arhipova, N.; Gaitnieks, T.; Stenlid, J.; Vasaitis, R. Natural infection of Fraxinus excelsior seeds by Chalara fraxinea. For. Pathol. 2013, 43, 83-85.

85. Marčiulynienè, D.; Davydenko, K.; Stenlid, J.; Shabunin, D.; Cleary, M. Fraxinus excelsior seed is not a probable introduction pathway for Hymenoscyphus fraxineus. For. Pathol. 2017, e12392. [CrossRef]

86. Cordell, C.E.; Anderson, R.L.; Hoffard, W.H.; Landis, T.D.; Smith, R.S.J.; Toko, H.V. Forest Nursery Pests; USDA Forest Service: Washington, DC, USA, 1989.

87. European-Union. Council directive 1999/105/EC of 22 December 1999 on the marketing of forest reproductive material. Off. J. Eur. Commun. 2000, L11, 17-40. Available online: https://eur-lex.europa.eu/legal-content/EN/ ALL/?uri=CELEX\%3A31999L0105 (accessed on 25 March 2019).

88. European-Union. Commission implementing directive 2017/1279 of 41 July 2017, amending Council Directive 2000/29/EC on protective measures against the introduction into the community of organisms harmful to plants or plant products and against their spread within the community. Off. J. Eur. Union 2017, L184, 33-62. Available online: https://www.agriculture.gov.ie/media/migration/farmingsectors/planthealthandtrade/ tradernotices2017/CommImpDirEU181217.pdf (accessed on 25 March 2019). 